\title{
In-vitro functional efficacy of extracts from Caucasian Rhododendron (Rhododendron caucasicum) and Rkatsiteli wines as pancreatic lipase inhibitors
}

\section{Zhuzha Khatchapuridze ${ }^{1}$, Givi Gugulashvili², Vitali Ghvachliani2, Angelika Ploeger $^{3}$, Levan Gulua ${ }^{1}$, Tamar Turmanidze ${ }^{1}$}

\author{
1 - Agricultural University of Georgia, Tbilisi, Georgia \\ 2 - Georgian Technical University, Tbilisi, Georgia \\ 3 - University of Kassel, Kassel, Germany
}

Keywords:

Wine

Caucasian

Rhododendron

Rkatsiteli

Orlistat

Antioxidant

Pancreatic lipase

\section{Article history:}

Received

20.09.2020

Received in revised

form 11.01.2020

Accepted

25.03.2021

Corresponding author:

Tamar Turmanidze E-mail: tamar.turmanidze@ agruni.edu.ge

\section{DOI:}

$10.24263 / 2304-$

974X-2021-10-1-4

\section{Abstract}

Introduction. The aim of the research is to determine the inhibitory activities of Caucasian Rhododendron (Rhododendron caucasicum) and Rkatsiteli wines against pancreatic lipase.

Materials and methods. The leaves of Caucasian Rhododendron were collected in the Upper Svaneti region. Wines were made of Rkatsiteli grape variety. Titrimetric method was used to determine lipase activity, total phenolic content (TPC), and Ferric reducing ability of plasma (FRAP) were determined spectrophotometrically.

Results and discussion. We could demonstrate in this research project a high correlation between TPC and antioxidant activity (AOA) in all samples. Pearson's correlation coefficient $\left(\mathrm{R}^{2}\right)$ for the Caucasian Rhododendron samples and wine samples were 0.9758 and 0.9556, respectively. The average TPC in Caucasian Rhododendron was found to vary from $13.00 \pm 0.48$ to $19.48 \pm 0.84 \%$ Gallic acid equivalent (GAE) based on dry matter content. The 3-rd sample of Caucasian Rhododendron revealed the highest TPC, $19.48 \pm 0.84 \%$ GAE, and possessed an AOA of 16.10 \pm 0.32 . No significant difference was observed between the third and first sample of $17.97 \pm 0.42 \%$ GAE and $15.35 \pm 0.74$ AOA $(p<0.05)$. Even though the fourth sample showed the lowest TPC and AOA, its lipase inhibitory activity closely resembled Orlistat. $t$ seems that polyphenol, which is most responsible for anti-lipase activity of Caucasian Rhododendron is easily oxidised in the air. Consequently, similar technology to green tea processing allows retaining most of the polyphenol in the vine sample. In the rest of the samples, this substance underwent oxidation by molecular oxygen. These results indicated that the treatment of Rhododendron samples could influence the composition of bioactive compounds. The results obtained herein allow one to conclude that white wines made with Kakhetian technology are rich with bioactive compounds and possess higher antioxidant activity and Lipase inhibitory activity when compared to wines made with European technology.

Conclusion. Extracts from Caucasian Rhododendron can act as a promising natural inhibitor and reduce dietary cholesterol' absorption. Based on a dry matter content, Caucasian Rhododendron offered better inhibitory activity than white wine samples. 


\section{- Food Technology -}

\section{Introduction}

The link between obesity and the intake of a lipid-rich diet (Bray and Popkin, 1998; Hariri and Thibault, 2010) raised attention towards inhibition of pancreatic lipase (P.L.) (Tian-Tian et al., 2020) P.L. is an enzyme that plays a central role in lipid digestion, it breaks down the food source's oil into fatty acids and glycerol that can be easily absorbed and digested by intestines (Lowe, 1997). Using lipase inhibitors to reduce dietary fat absorption and develop anti-obesity agent is an attractive approach, and currently, one of the main strategies in the management and treatment of obesity (Apovian et al., 2015; McCafferty et al., 2020). Lipase inhibitors have been proven to be relatively safe and have been identified as a rational and valid target of the molecular level to control obesity (Kaumar and Chauhan, 2021). Despite this fact, currently, only Orlistat ${ }^{\circledR}$ (Xenical), a hydrogenated derivative of Lipstatin, that inhibits lipase activity (Heck et al., 2000), has been approved in clinical use for the management and treatment of obesity (Bogarin and Chanoine, 2009; McClendon et al., 2009). Since the clinical utility of orlistat is limited (Cruz-Hernandez et al., 2010; Filippatos et al., 2008) and obesity remains a global health issue (Rössner, 2002; WHO, 2020), the search for new natural substances that show potent inhibitory activity against P.L. and have fewer side effects remains topical (Birari et al., 2007; De la Garza et al., 2011).

Large numbers of plants are being screened for potentially lipase inhibitory activity and a variety of phytochemicals have been identified, such as polysaccharides, polyphenols, terpene trilactones, alkaloids, saponins, and carotenoids (Bajes et al., 2020). A great deal of research showed that the class of polyphenols represents one of the most important sources of potential P.L. inhibitors (Buchholz and Melzig, 2015; Martinez-Gonzalez et al., 2017) P.L. inhibition is being reported by numerous polyphenolic compound-rich foodstuffs, including medicinal plants (Seyedan et al., 2015; Zheng et al., 2010), berries (McDougall et al., 2009, Sosnowska et al., 2018), cocoa (Gu et al., 2011), tea (Glisan et al., 2017; Gondoin et al., 2010), grape seeds ((Moreno et al., 2003, Tian et al., 2010), etc.

Additionally, Paraguariensis leaves, popularly known as Yerba Mate beverages, have been reported to have biological activities and considered as a potent anti-obesity reagent (probably, due to their high content of total phenolics) (Kim et al., 2015). Because the mate's raw material is not growing in Georgia, several studies have been conducted to discover the possibility of obtaining yerba mate from the plant Rhododendron caucasicum, or Caucasian Rhododendron ) (Megrelidze et al., 2020; Melkadze and Kereselidze, 2010). These studies have proved that Paraguariensis leaves can be replaced by Rhododendron caucasicum, since they are similar in chemical composition and health effects (both positive and penalty ones). However, there have been no data published regarding anti-lipase activity, total phenolic content (TPC) and antioxidant activity (AOA) of Caucasian Rhododendron itself.

In this regard, the aim of the present study is to investigate a new agent (Caucasian Rhododendron) for its ability to impair digestion and assimilation of dietary fat and to determine TPC and AOA of it. According to the published data, Georgian wines have also displayed a relationship between total phenolic content and their inhibitory activity against P.L. (Gulua et al., 2018). Therefore, this research aims to compare the anti-lipase activity and bioactive compound contents between Caucasian Rhododendron's extracts and white wines made from Rkatsiteli, which is the leading white grape variety in Georgia (Robinson et al., 2012) and to assess their potential use in the management of obesity compared to Orlistat. 


\section{Materials and methods}

\section{Chemicals}

Ascorbic acid, Olive Oil, Sodium Hydroxide, Potassium dihydrogen Phosphate, FolinCiocalteu reagent, Detergent Tween 80, Sodium carbonate, Ethyl acetate and methanol were purchased from Sigma - Aldrich (Steinheim, Germany), TPTZ-2,4,6-Tris (2-pyridyl)-striazine (Sigma - Aldrich, Switzerland), hydrochloric acid, formic acid and phosphoric acid were provided by Merck (Darmstadt, Germany), Lipase concentrate - H.P. was purchased for Integrative Therapeutics, LLC (USA). Orlistat ${ }^{\circledR}$ (trade name Xenical) by Roche (Italy) was purchased at the local pharmacy. All other reagents were commercially available at the local market and were of analytical grades.

\section{Materials - Sample collection}

\section{Wine samples}

Four commercially produced white dry wines (see table 1), made from autochthonous and leading white grape variety (Rkatsiteli) grown in the region of Kakheti, were chosen. The wine samples for the experiment were chosen at random. The wines, packed in glass bottles, were purchased from the local supermarket and stored at room temperature until being analysed. We did that because it is as consumers would do, promising in vivo potent lipase inhibitory activity can be the definite factor behind consumer decision making.

Rkatsiteli Wine samples

Table 1

\begin{tabular}{|l|c|c|l|}
\hline \multicolumn{1}{|c|}{ Name of the bottle } & Vintage & $\begin{array}{c}\text { Alcoholic } \\
\text { strength \% }\end{array}$ & Technological treatment \\
\hline $\begin{array}{l}\text { Vine Ponto - Rkatsiteli white } \\
\text { dry }\end{array}$ & 2016 & 12.5 & $\begin{array}{l}\text { Qvevri and Oak Barrel } \\
\text { technology }\end{array}$ \\
\hline Glekhuri - Rkatsiteli Qvevri; & 2017 & 13 & Qvevri technology \\
\hline Vaziani, Rkatsiteli & 2016 & 12.5 & $\begin{array}{l}\text { Classic and Oak Barrel } \\
\text { technology }\end{array}$ \\
\hline Kindzmarauli Marani Rkatsiteli & 2018 & 13 & Classic technology \\
\hline
\end{tabular}

\section{Caucasian Rhododendron samples}

Caucasian Rhododendron (Rhododendron caucasicum) samples were collected in the Upper Svaneti region, in the village of Ushguli $\left(42.917797^{\circ} \mathrm{N} 43.015672^{\circ} \mathrm{E}\right)$, at an altitude of $2100 \mathrm{~m}$. The samples were picked during the harvest-time, June 10-20, 2020; mainly 34th leaves were collected.

\section{Caucasian Rhododendron sample preparation}

The samples were treated with four different processing methods, as follows:

1. Sun-dried: samples were drying for 5 days and nights at the average daytime temperature $27-28{ }^{\circ} \mathrm{C}$; 
2. Shade-dried: drying lasted for 12 days and the average daily temperature was $16-17$ ${ }^{\circ} \mathrm{C}$;

3. The Classical technological scheme of black tea processing, including withering at room temperature, rolling, fermentation and drying (Samarasingham, 2009).

4. The classical technical method of green tea processing, including fixation with roasting, thermal treatment rolling and drying (Singh et al., 2014).

\section{Preparation of Caucasian Rhododendron extracts}

The Caucasian Rhododendron extracts were prepared by extracting $3 \mathrm{~g}$ of dried samples in $300 \mathrm{~mL}$ of boiling deionised water and infusing for $15 \mathrm{~min}$. Subsequently, the extract was gently stirred, filtered under vacuum, cooled down to room temperature, and the final volume was brought up to $500 \mathrm{~mL}$ with cooled deionised water. Extracts were stored at $+4{ }^{\circ} \mathrm{C}$ for the analyses.

\section{Determination of moisture content $(\%)$}

Moisture content in dried leaves of Caucasian Rhododendron was determined with a drying subsample $(2 \mathrm{~g})$ at $105^{\circ} \mathrm{C}$ to constant weight. SFY-20 infrared rapid moisture tester (Hangzhou Hengqing Technology Co., LTD, China) was used for quick and reliable determination of the moisture content of samples.

\section{Total dry matter}

For measurement of non-volatile dry matter, a $50 \mathrm{~mL}$ sample of wine and tea extracts were aliquoted into a porcelain dish. Extracts were filtered initially. The dish was then placed onto a boiling water bath until the evaporation of water, alcohol (in case of wine), and other volatile compounds had occurred. The residual moisture was then evaporated from the samples by oven drying at $105^{\circ} \mathrm{C}$ for $16 \mathrm{~h}$. Total dry matter was determined gravimetrically as the residue remaining after drying.

\section{Determination of total phenolic content (TPC)}

The total phenolic content (TPC) was determined spectrophotometrically (UV 1609, A\&E Lab Co LTD, U.K), using gallic acid (G.A.) as standard, according to the method described by the International Organization for Standardization ISO 14502-1 (ISO, 2005).

Briefly, the diluted sample extract $(1 \mathrm{~mL})$ and diluted G.A. working standard solutions (10-50 $\left.\mu \mathrm{g} \mathrm{mL}^{-1}\right)$ were pipetted into separate disposable test tubes. Additionally, $5 \mathrm{~mL}$ of (1/10) diluted Folin-Ciocalteu phenol reagent in water was added into each tube. 8 min after, $7.5 \%(\mathrm{w} / \mathrm{v})$ of Sodium Carbonate solution $(4 \mathrm{~mL})$ was added into each test tube. The mixtures were mixed well, and the tubes were allowed to stand for another 60 minutes at room temperature. Then their optical densities against the water were measured at $765 \mathrm{~nm}$, with a $10 \mathrm{~mm}$ path length cell.

The calibration curve of absorbance vs concentration of a standard solution (Pearson's correlation coefficient: $\mathrm{r}^{2}=0.9918$ ) was used to quantify TPC content. Results were expressed as gallic acid equivalents (GAE) in $\mathrm{mg} / \mathrm{L}$ of wine and in $\mathrm{g} / 100 \mathrm{~g}$ of the dried matter of Caucasian Rhododendron. 


\section{Ferric reducing ability of plasma (FRAP) assay for total antioxidant activity}

Ferric reducing ability of plasma (FRAP) assay has been applied for the evaluation of the total antioxidant activity (AOA), according to Benzie and Strain, 1996, with slight modifications. The working FRAP reagent was prepared freshly by mixing acetate buffer (300 mM, pH 3.6), 2,4,6- tripyridyl-s-triazine (TPTZ) solution (10 mM, dissolved in $40 \mathrm{mM}$ of $\mathrm{HCl}$ ) and Ferric Chloride solution ( $20 \mathrm{mM}$ ) in the ratio 10:1:1. The FRAP reagent and vitamin $\mathrm{C}(1 \mathrm{mM})$ were separately incubated for $15 \mathrm{~min}$ at $37{ }^{\circ} \mathrm{C} .3 \mathrm{~mL}$ of working reagent was mixed with 100 microliters of the diluted sample. Ascorbic acid was used as a standard. The reduction was monitored at $593 \mathrm{~nm}$, and the absorbance was recorded after $4 \mathrm{~min}$. FRAP values of samples were compared to that of ascorbic acid and expressed as vitamin $\mathrm{C}$ equivalents per $100 \mathrm{~g}$ of dry matter of Rhododendron and mg per 1 litre of wine.

\section{Determination of Lipase inhibitory activity}

Titrimetric assay method was used to determine lipase activity as reported by Stoytcheva et al., 2012, with minor modifications.

Briefly, the initial reaction mixture consisted of $2.5 \mathrm{~mL}$ of deionised water, $1 \mathrm{~mL} 200$ $\mathrm{mM}$ Tris $\mathrm{HCl}$ buffer (pH 7.2), $3 \mathrm{~mL}$ of olive oil, and $0.5 \mathrm{~mL}$ of detergent (Tween 80 ). To obtain a good result, the solution was vigorously mixed on a magnetic stirrer for $15 \mathrm{~min}$. Subsequently, $110 \mathrm{mg}$ of the lipase concentrate was then added to the emulsified mixture, which was then incubated at $37^{\circ} \mathrm{C}$ for exactly $30 \mathrm{~min}$. At the end of the incubation, $3 \mathrm{~mL}$ of $95 \%$ ethanol was added, and the final reaction mixture was titrated with $50 \mathrm{mM} \mathrm{NaOH}$ until the value of $\mathrm{pH} 9$ at automatic titrator (ZDJ-4A, INESA Scientific Instrument Co., Ltd, Anting Shanghai, China) was achieved. Blank titration was carried out as above, but without lipase, in test samples potent inhibitors were involved. One unit of lipase activity is defined as the amount of enzyme that hydrolyses 1.0 micro equivalent of fatty acid from a triglyceride in one hour at $\mathrm{pH} 7.2$ at $37^{\circ} \mathrm{C}$. Lipase activity was calculated using following equation:

$$
\text { Lipase Units }=\frac{(\mathrm{A}-\mathrm{B})(1000)(2)(\mathrm{DF})}{(1)}
$$

where $\mathrm{A}=$ volume of $50 \mathrm{mM} \mathrm{NaOH}$ consumed by the test sample in $\mathrm{mL}$;

$\mathrm{B}=$ volume of $50 \mathrm{mM} \mathrm{NaOH}$ consumed by the blank sample in $\mathrm{mL}$;

$1000=$ conversion factor from milli equivalents to micro equivalents;

2 = time conversion factor from 30 min to 1 hour;

$\mathrm{DF}=$ dilution factor

$1=$ Volume (in millilitre) of enzyme used

The percentage of inhibition was calculated in the presence and absence of inhibitors. Orlistat was used as a standard inhibitor. Lipase activity was measured in the presence of Orlistat $(10 \mathrm{mg})$ and the percent of inhibition was calculated per $1 \mathrm{mg}$ of Orlistat.

To measure the percentage of lipase inhibition $1 \mathrm{~mL}$ of potent inhibitors (Caucasian Rhododendron extracts and Rkatsiteli wines) were added separately to the initial mixture and the following procedures were identical to those described previously. The effect of inhibition of the samples was calculated as the percent of Orlistat inhibition value. 


\section{Statistical analysis}

The data represents the mean of a minimum three replicates \pm standard deviation (S.D.). Data were subjected to the one-way ANOVA and Tukey's HSD tests. One-way analysis of variance (ANOVA) was done to analyse the significance in the variation of the means between the experimental samples. Tukey's HSD test was used to differentiate between the mean values. All calculations were performed with Microsoft Excel for Microsoft 365 MSO with PHstat 2 version 3.11 add-in assistance.

\section{Results and discussion}

\section{Moisture content (\%) of the Caucasian Rhododendron dried samples}

The moisture content of the Rhododendron samples was varying from $7.82 \pm 0.52$ up to $8.71 \pm 0.65 \%$. In particular, the moisture content of the sun-dried sample was equal to $7.82 \%$ \pm 0.52 , shade-dried $-8.63 \% \pm 0.18$. The moisture content of the sample obtained by black tea making technology was equal to $8.21 \% \pm 0.74$, while that of the sample obtained by green tea technology was $8.71 \% \pm 0.65$ (Table 2).

Moisture content (\%) of the Caucasian Rhododendron dried samples

Table 2

\begin{tabular}{|ll|c|}
\hline \multicolumn{1}{|c|}{ Sample name } & Moisture content (\%) \\
\hline 1. & Sun-dried & $7.82 \pm 0.52$ \\
\hline 2. & Shade-dried & $8.63 \pm 0.18$ \\
\hline 3. & Black tea like processing technology & $8.21 \pm 0.74$ \\
\hline 4. & Green tea like processing technology & $8.71 \pm 0.65$ \\
\hline
\end{tabular}

Despite the different treatments, as shown in Table 2, there was no statistically significant difference between the samples' moisture contents.

\section{Total phenolic content}

As shown in Figure 1, the average total phenolic content in Caucasian Rhododendron was found to vary from $13.00 \pm 0.48$ to $19.48 \pm 0.84 \%$ GAE based on dry matter content. The highest TPC $19.48 \pm 0.84 \%$ GAE was found in Caucasian Rhododendron, which was processed with the classical technological scheme of black tea. Rhododendron treated with green tea like processing technology showed the lowest TPC 13.00 $\pm 0.48 \%$ GAE, Sun-dried and shade-dried Rhododendron obtained 17.97 \pm 0.42 and 15.32 $\pm 0.55 \%$ GAEs respectively. 


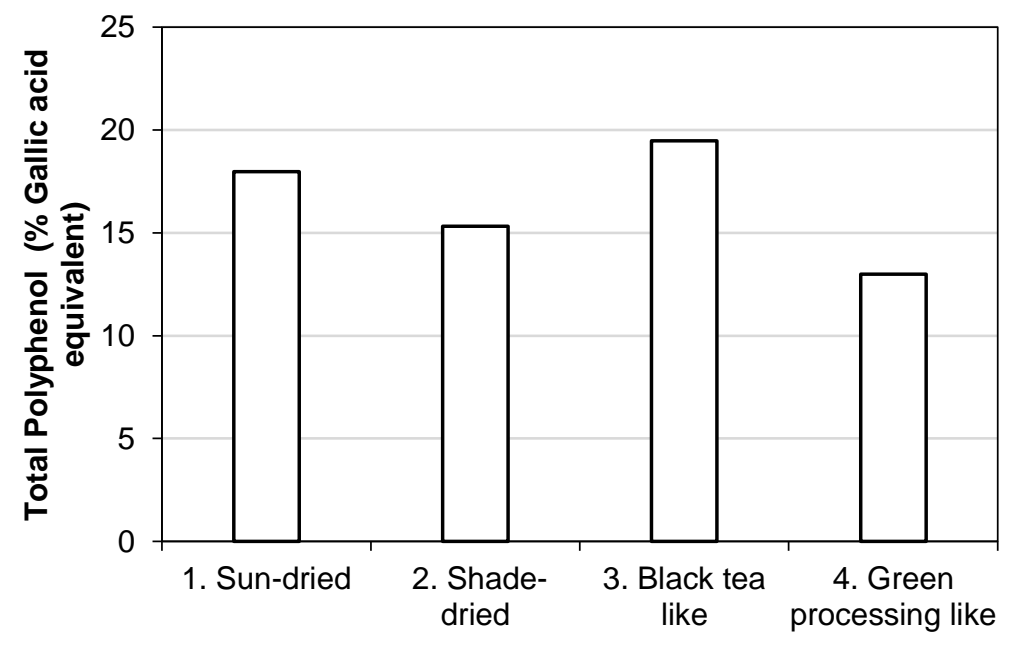

\section{Caucasian Rhododendron samples}

Figure 1. Total phenolic content of Rhododendron dried samples based on the dry matter content

The phenolics have been oxidised during the drying process. Although fewer phenolics have been oxidised during sun drying than shade drying. This can be explained by the difference in the drying time duration. The roasting process destroyed more phenolics than by enzymatic oxidation in the black tea like processing. The results reported by Bastos et al., 2007 and Prasanna et al., 2018 showed that the roasting process leads to a significant alteration of major bioactive and antioxidant activities in all leafy vegetables and yerba mate beverages tested.

Most phenolics were probably lost due to insufficient inactivation of the enzyme phenolic oxidase (PPO) during the fixation process. Also, part of the phenolics was nonenzymatically oxidised during the processing. The amount of phenolics oxidised by PPO in black tea like processed leaves was lower than in green tea like processed Rhododendron leaves. There was no significant difference between the 1 st and 3rd samples $(p<0.05)$.

\section{Total phenolic content in wine}

As Figure 2 shows, phenolic content in wines was statistically significantly different. The highest phenolic content was found in the Rkatsiteli sample from brand Qvevri, $2901.626 \pm 34.648 \mathrm{mg} / \mathrm{L}$ GAE. The phenolic content of brand Vine Ponto $(2515.447$ ( \pm 137.972) was higher than that obtained from brands Vaziani and Qindzmarauli Marani, $489.577( \pm 36.112)$ and $190.243( \pm 11.498) \mathrm{mg} / \mathrm{L}$ GAE respectively.

As seen from the table 1, wines differed by processing technology, they were processed by classic (European) technology and Kakhetian Qvevri technology. According to the Kakhetian Qvevri technology, grapes along with other parts i.e., cluster (stem, skin, seeds) are crushed in a juicer, then placed and sealed in a fermentation vessel called Qvevri, which is dug in the ground (UNESCO, 2013).

During fermentation, phenolic compounds are extracted in large quantities from the stem, peel and grapes, which explains the reason why wines of Kakhetian type showed the highest phenolic content than those of European type. Similar results were reported by A. Shalashvili et al., 2010. 


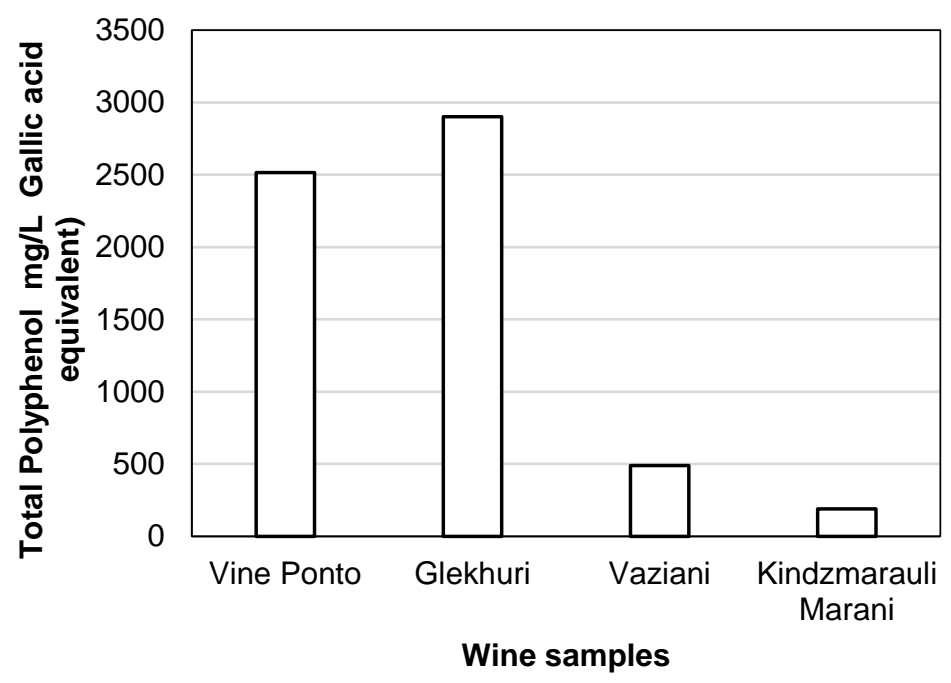

Figure 2. Total phenolic content in wine samples mg/L Gallic acid equivalent

\section{Ferric reducing ability of plasma FRAP}

FRAP assay (Figure 3) showed that a 3-rd sample of Caucasian Rhododendron revealed the highest AOA 16.10 \pm 0.32 . However, no significant difference was observed between the third and first sample of $15.35 \pm 0.74(\mathrm{p}<0.05)$. These samples were followed by the $2 \mathrm{nd}$ sample $11.03 \pm 0.53$ and the 4 th sample had the lowest antioxidant activity (AOA) $8.93 \pm 0.19$.

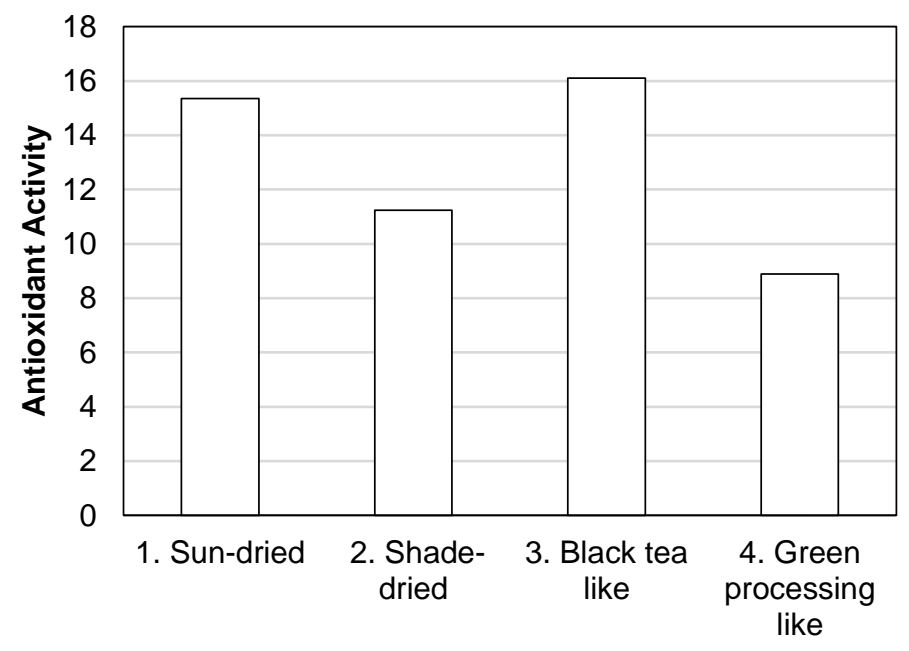

Caucasian Rhododendron samples

Figure 3. Antioxidant activity of Caucasian Rhododendron samples based on the dry matter content $(\mathrm{g} / \mathbf{1 0 0} \mathrm{g})$ 
For the wines studied herein, Wines made with Kakhetian technology possess noticeably higher antioxidant activity compared to those made with European technology (Figure 4). The highest AOA was found in the Rkatsiteli sample from brand Vine Ponto, $2413.275 \pm 53.247 \mathrm{mg} / \mathrm{L}$. The antioxidant activity of brand Qvevri $(2177.584( \pm 130.730)$ was higher than that obtained from brands Qindzmaraulis Marani and Vaziani, $199.825( \pm 53.247)$ and $179.330( \pm 62.121) \mathrm{mg} / \mathrm{L}$, respectively.

The wines fermented in qvevri and then moved to oak barrels showed the highest AOA, compared to those that have been fermented and stored in Qvevri. These results are in good agreement with results published by Shalasvili et al., 2010 and Tauchen et al., 2015. Tauchen et al. compared the Antioxidant effect and phenolics content of different wines. According to this research, among white wines, Georgian wines possessed significantly higher antioxidant activity in comparison with white wines prepared by the standard European method. This also can be explained by different processing technology.

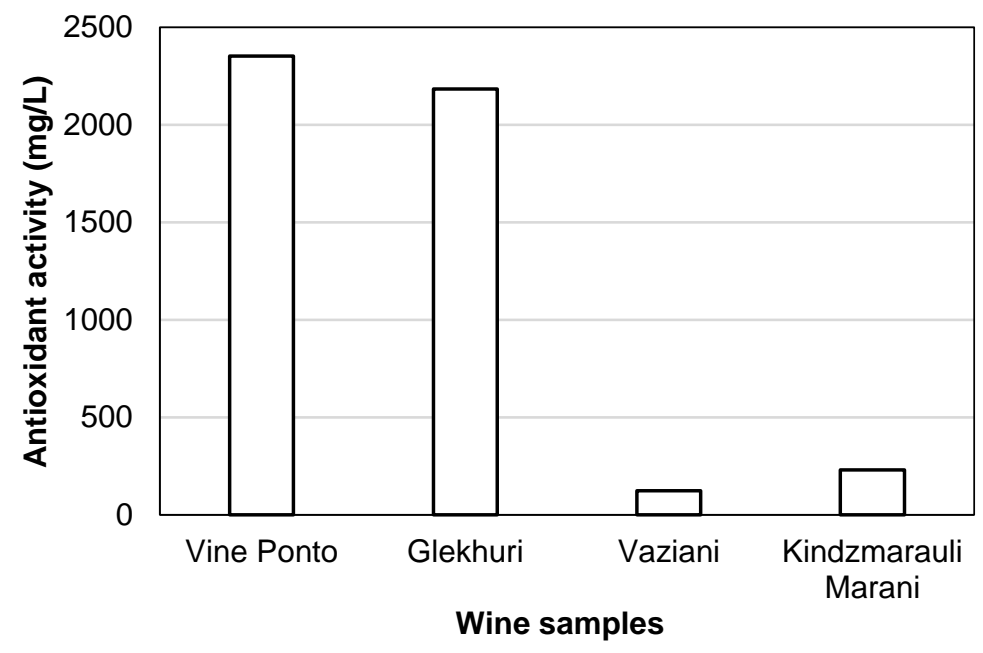

Figure 4. Antioxidant activity $\mathrm{mg} / \mathrm{L}$, by brand of Rkatsiteli

\section{Anti-lipase activity of samples}

The anti-lipase activities (effect of inhibition) of $1 \mathrm{mg}$ dried samples of Caucasian Rhododendron are shown in Table 3. The anti-lipase activities (effect of inhibition) were calculated as the percent of $1 \mathrm{mg}$ Orlistat inhibition value. Orlistat ${ }^{\circledR}$ itself $(10 \mathrm{mg})$ showed $75.84 \%$ inhibition of lipase activity.

Table 3

Effect of inhibition per $1 \mathrm{mg}$ dry matter of Caucasian Rhododendron samples as the percent of Orlistat inhibition value

\begin{tabular}{|l|l|}
\hline $\begin{array}{l}\text { Treating technology of Caucasian } \\
\text { Rhododendron samples }\end{array}$ & $\begin{array}{l}\text { Effect of inhibition as the percent of } \\
\text { Orlistat inhibition value }\end{array}$ \\
\hline Sun-dried & 69.9 \\
\hline Shade-dried & 85.35 \\
\hline Black tea like processing technology & 86.15 \\
\hline Green tea like processing technology & 99.63 \\
\hline
\end{tabular}


As it can be seen from Table 2, green tea-like processing technology treated samples showed the highest anti-lipase activity. Moreover, the effect of inhibition was almost equal to the one of Orlistat. It seems that phenolic, which is most responsible for anti-lipase activity of Caucasian Rhododendron, is easily oxidised in the air; therefore, most of this substance was retained in the sample made by green tea like processing technology. Regarding the other samples, this substance underwent oxidation by molecular oxygen.

The effects of inhibition of $1 \mathrm{~mL}$ wine samples depicted as the percent of $1 \mathrm{mg}$ Orlistat inhibition value are shown in Table 3.

Table 4*

Effect of inhibition of white wine samples as the percent of Orlistat inhibition value

\begin{tabular}{|l|l|}
\hline Wine producer & Effect of inhibition as the percent of Orlistat inhibition value* \\
\hline Vine Ponto & 26.75 \\
\hline Qvevri Glekhuri & 20.5 \\
\hline Vaziani & 4.91 \\
\hline Kindzmarauli Marani & 14.91 \\
\hline
\end{tabular}

*- Inhibition by wines was calculated as per $1 \mathrm{~mL}$, inhibition by Orlistat was calculated as per $1 \mathrm{mg}$.

As it is seen from Table 4, wines made with Kakhetian technology showed a higher inhibition effect than those made with European technology. In overall, these values were statistically significant ( $\mathrm{p}>0.05)$.

A high correlation was demonstrated in this work between the TPC and AOA in all samples. Pearson's correlation coefficient (r2) for the Caucasian Rhododendron samples (Figure 5) and white wine (Figure 6) samples was 0.9758 and 0.9556, respectively. Several data have been published regarding the relationship between antioxidant capacity and total phenolic content of different wines (Gulua et al., 2018), (Paixao et al., 2007).

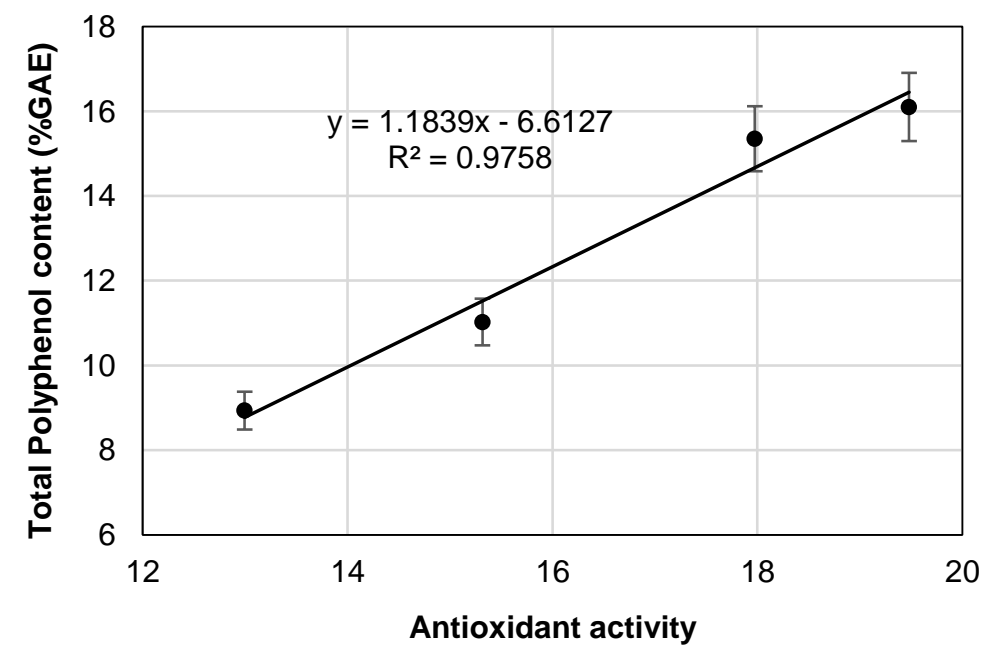

Figure 5. Correlation between the total phenolic content and antioxidant activity of Caucasian Rhododendron samples 


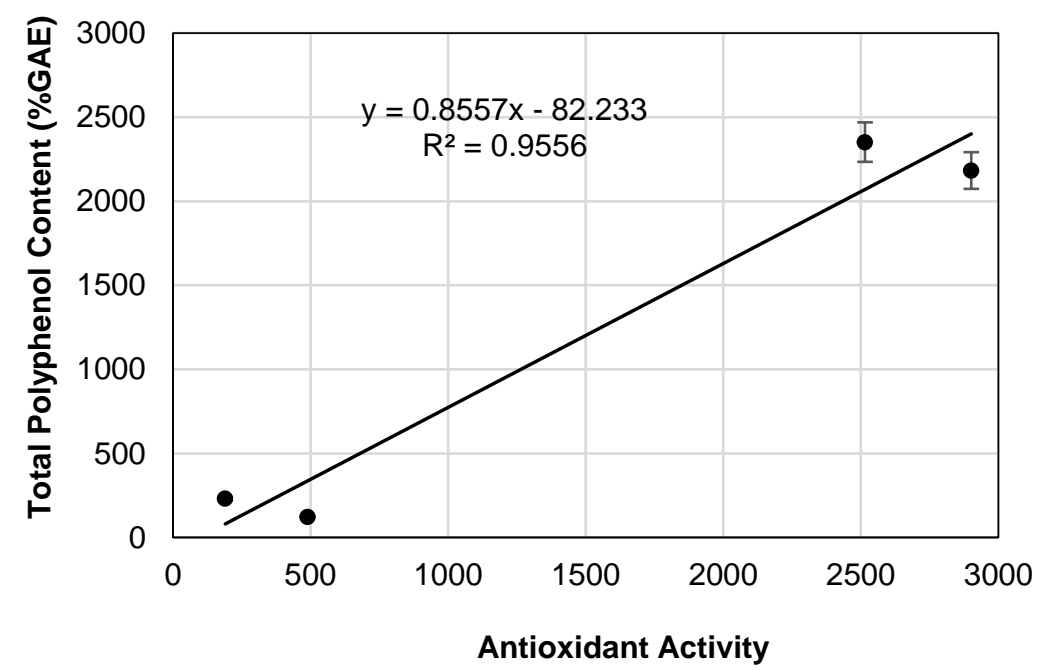

Figure 6. Correlation between the total phenolic content and antioxidant activity of Rkatsiteli wine samples

Lipase inhibitory activity of Rkatsiteli samples displayed a higher correlation with AOA (Pearson's correlation coefficient $\left(\mathrm{r}^{2}\right)$ 0.88, than with total phenolic content (Pearson's correlation coefficient $\left.\left(\mathrm{r}^{2}\right) 0.78\right)$.

Tested wine samples were differentiated according to production technology, vintage, and alcohol content (see table 1). Probably due to these reasons, this experiment showed the range of results in wine and furthermore in-depth investigations are needed.

\section{Conclusion}

1. Caucasian Rhododendron can be used as a potent lipase inhibitor; it showed better inhibitory activity than white wine samples. Thus, Caucasian Rhododendron could be a reasonable natural resource for the preparation of ingredients with lipase inhibitory activity. However, there are further studies needed to obtain detailed information regarding the influence of treatment methods on bioactive compounds and lipase inhibitory activity.

2. Extracts from Caucasian Rhododendron can act as a promising natural inhibitor of pancreatic lipase and reduce dietary cholesterol' absorption.

3. The treatment of Rhododendron samples could influence the composition of bioactive compounds.

4. The Caucasian Rhododendron sample treated with the classical technical method of green tea processing showed the showed the highest inhibitory activities against pancreatic lipase. Moreover, the effect of inhibition was almost equal to the one of Orlistat.

5. Winemaking technology effects on phenolic composition in Rkatsiteli wine samples. White wines made with Kakhetian technology are rich with bioactive compounds and possess higher antioxidant activity and Lipase inhibitory activity than wines made with classical (European) technology. 


\section{Acknowledgment}

The authors gratefully acknowledge the financial support provided by the Shota Rustaveli National Science Foundation of Georgia (SRNSFG) (grant number FR-18-566. The Biotechnological bases for making Mate type tea) and Volkswagen (VW) Foundation (Volkswagen Stiftung). Zhuzha Khatchapuridze is the $\mathrm{PhD}$ student supported by Sustainable Agriculture and Food Sytems (SAFS) program.

\section{References}

Apovian C.M., Aronne L.J., Bessesen D.H., McDonnell M.E., Murad M.H., Pagotto U., Ryan D.H., Still C.D. (2015), Pharmacological management of obesity: An endocrine Society clinical practice guideline, Journal of Clinical Endocrinology \& Metabolism, 100(2), pp. 342362.

Bajes, H. R., Almasri, I., \& Bustanji, Y. (2020), Plant Products and Their Inhibitory Activity Against Pancreatic Lipase, Revista Brasileira de Farmacognosia, 30, pp. 321-330.

Bastos D.H.M., Saldanha L.A., Catharino R.R., Sawaya A.C.H.F., Cunha I.B.S., Carvalho P.O., Eberlin M.M. (2007), Phenolic antioxidants identified by ESI-MS from yerba mate (Ilex paraguariensis) and green tea (Camelia sinensis) extracts, Molecules, 12, pp. 423 432.

Benzie I.F., Strain J.J. (1996), The ferric reducing ability of plasma (FRAP) as measure of "antioxidant power": the FRAP assay, Analytical Biochemistry, 239(1), pp. 70-76.

Birari R.B., Bhutani K.K.(2007), Pancreatic lipase inhibitors from natural sources: unexplored potential, Drug Discovery Today, 12 (19), pp. 879-889.

Bogarin R., Chanoine J.P. (2009), Efficacy, Safety and Tolerability of Orlistat, a Lipase Inhibitor, in the Treatment of Adolescent Weight Excess, Therapy, 6(1), pp. 23-30.

Bray G.A., Popkin B.M. (1998), Dietary fat intake does affect obesity!, The American Journal of Clinical Nutrition, 68 (6), pp. 1157-1173.

Buchholz T., Melzig M.F. (2015), Polyphenolic compounds as pancreatic lipase inhibitors, Planta Medica, 81(10), pp. 771-783.

Cruz-Hernandez C, Oliveira M, Pescia G, Moulin J, Masserey-Elmelegy I, Dionisi F, Destaillats F. (2010), Lipase inhibitor orlistat decreases incorporation of eicosapentaenoic and docosahexaenoic acids in rat tissues, Nutrition Research, 30(2), pp. 134-140.

De la Garza A., Milagro F., Boque N., Campión J., Martínez J. (2011), Natural Inhibitors of Pancreatic Lipase as New Players in Obesity Treatment, Planta Medica, 77(08), pp. 773785.

Filippatos T., Derdemezis C., Gazi I., Nakou E., Mikhailidis D., Elisaf M. (2008), Orlistat-associated adverse effects and drug interactions: a critical review, Drug Safety, 31(1), pp. 53-65.

Glisan S. L., Grove, K. A., Yennawar, N. H., \& Lambert, J. D. (2017), Inhibition of pancreatic lipase by black tea theaflavins: Comparative enzymology and in silico modeling studies, Food chemistry, 216, pp. 296-300.

Gondoin A., Grussu D., Stewart D., McDougall G.J. (2010), White and green tea polyphenols inhibit pancreatic lipase in vitro, Food Research International, 43(5), pp. 15371544.

Gu Y., Hurst W.J., Stuart D.A., Lambert J.D. (2011). Inhibition of key digestive enzymes by cocoa extracts and procyanidins, Journal of agricultural and food chemistry, 59(10), pp. $5305-5311$. 
Gulua L., Nikolaishvili L., Turmanidze T., Jgenti M., Bezhuashvili M., FitzGerald R.J. (2018), Chemical constituents, antioxidant and anti-lipase activity of some wines produced in Georgia, Ukrainian Food Journal, 7(2), pp. 177-191.

Hariri N., Thibault L. (2010), High-fat diet-induced obesity in animal models, Nutrition Research Reviews, 23(2), pp. 270-299.

Heck A.M., Yanovski J.A., Calis K.A. (2000), Orlistat, a new lipase inhibitor for the management of obesity, Pharmacotherapy, 20(3) pp. 270-279.

International Organization for Standardization. ( 2005), Determination of substances characteristic of green and blck tea. Part 1: Content of total phenolics in tea, Colorimetric method using Folin-Ciocalteu reagent, ISO 14502-1.

Kim S.Y., Oh M.R., Kim M.G., Chae H.J., Chae S.W. (2015), Anti-obesity effects of yerba mate (Ilex Paraguariensis): A randomized, double-blind, placebo-controlled clinical trial, BMC Complementary and Alternative Medicine, 15, pg. 338.

Kumar A., Chauhan S. (2021), Pancreatic lipase inhibitors: The road voyaged and successes, Life Sciences, 271, 119115, ISSN 0024-3205.

Lowe M.E. (1997), Structure and function of pancreatic lipase and colipase, Annual Review of Nutrition, 17, pp. 141-158.

Martinez-Gonzalez, A.I.; Alvarez-Parrilla, E.; Díaz-Sánchez, Á.G.; de la Rosa, L.A.; Núñez-Gastélum, J.A.; Vazquez-Flores, A.A.; Gonzalez-Aguilar, G.A. (2017), In vitro Inhibition of Pancreatic Lipase by Phenolics: A Kinetic, Fluorescence Spectroscopy and Molecular Docking Study, Food Technology and Biotechnology, 55, pp. 519-530.

McCafferty B.J., Hill J.O., Gunn A.J. (2020), Obesity: Scope, Lifestyle Interventions, and Medical Management, Techniques in Vascular and Interventional Radiology, 23 (1), 100653.

McClendon K.S., Riche D.M., Uwaifo G.I. (2009), Orlistat: current status in clinical therapeutics, Expert Opinion on Drug Safety, 8(6), pp. 727-44.

McDougall G. J., Kulkarni N. N., Stewart D. (2009), Berry polyphenols inhibit pancreatic lipase activity in vitro, Food Chemistry, 115(1), pp. 193-199.

Megrelidze T., Isakadze T., Tabatadze L., Gugulashvili G., Kintsurashvili K., Kopaliani T. (2020), The possibility of obtaining tea such as Paraguayan mate from the Caucasian Rhododendron, European Science Review, 1-2, pp 73-77.

Melkadze R., Kereselidze O. (2010), Characteristics of Caucasian rhododendron leaves (Rhododendron caucasicum Pall) and prospects of its receiving a tea product such as "Mate", Journal of biology and Life science, 1(1), pp. 1-10.

Moreno D.A., Ilic N., Poulev A., Brasaemle D.L., Fried S.K., Raskin I. (2003), Inhibitory effects of grape seed extract on lipases, Nutrition, 19(10), pp. 876-879.

Paixao N., Perestrelo R., Marques J.C., Camara J.S. (2007), Relationship between antioxidant capacity and total phenolic content of red, rose and white wines, Food Chemistry, 105, pp. 204-214.

Prasanna K. D., Gunathilake P., Somathilaka Ranaweera K. K. D., Vasantha Rupasinghe H. P. (2018), Effect of Different Cooking Methods on Phenolics, Carotenoids and Antioxidant Activities of Selected Edible Leaves, Antioxidants, 7(9), p. 117. London.

Robinson J., Harding J., Vouillamoz J. (2012), Wine Grapes, Penguin Books Ltd.,

Rössner S. (2002), Obesity: the disease of twenty-first century, International Journal of Obesity, 26, S2-S4.

Samarasingham S. (2009), A Complete Book on Black Tea Manufacture Paperback, Stamford Lake Publications, Sri Lanka.

Seyedan, A., Alshawsh, M.A., Alshagga, M.A., Koosha, S., Mohamed, Z. (2015), Medicinal plants and their inhibitory activities against pancreatic lipase: A review, EvidenceBased Complementary and Alternative Medicine, 973143. 


\section{Food Technology}

Shalashvili A., Ugrekhelidze D., Targamadze I., Zambakhidze N., Tsereteli L. (2010), Comparison of wines of georgian (kakhethian) and european types according to quantitative content of phenolic compounds and antiradical efficency, Available at: http://www.domainegeorgia.com/photos/comparing\%20kvevri\%20wines.pdf

Singh V., Verma D.K., Singh G. (2014), Processing Technology and Health Benefits of Green Tea, Popular Kheti, 2(1), pp. 23-30.

Sosnowska D., Podsędek A., Redzynia M., Kucharska A.Z. (2018) Inhibitory effect of black chokeberry fruit polyphenols on pancreatic lipase - searching for most active inhibitors, Journal of Functional Foods, 49, pp. 196-204.

Stoytcheva M., Montero G., Zlatev R, León J.Á., Goche V. (2012), Analytical Methods for Lipases Activity Determination: A Review, Current Analytical Chemistry, 8(3), pp. 400407.

Tauchen J., Marsik P., Kvasnicova M., Maghradze D., Kokoska L., Vanek T., Landa P. (2015), In vitro antioxidant activity and phenolic composition of Georgian, Central and West European wines, Journal of Food Composition and Analysis, 41, pp. 113-121.

Tian Q., Wu Z.J., Huang D.R., Wang H., Zhang J., Fu H.L. (2010), Optimizing conditions for the isolation of pancreatic lipase inhibitive substance from grape seeds, Food Research and Development, 31(4) pp. 41-44.

Tian-Tian L., Xiao-Tian L., Qing-Xi C., Yan S. (2020), Lipase Inhibitors for Obesity: A Review, Biomedicine and Pharmacotherapy, 128, 110314.

United Nations Educational, Scientific and Cultural Organization (UNESCO). (2013), Ancient Georgian Traditional Qvevri winemaking method, The Representative List of the Intangible Cultural Heritage of Humanity, available at https://ich.unesco.org/en/RL/ancientgeorgian-traditional-qvevri-wine-making-method-00870

World Health Organization (WHO) Media Centre. (2020), Obesity and Overweight. Available at: https://www.who.int/news-room/fact-sheets/detail/obesity-and-overweight

Zheng C.D., Duan Y.Q., Gao J.M., Ruan, Z.G. (2010), Screening for anti-lipase properties of 37 traditional Chinese medicinal herbs, Journal of the Chinese Medical Association, 73(6), pp. 319-324. 